\title{
Effect of sample size on kinetic parameters of roughage and concentrated feeds by a semi-automated in vitro gas production system
}

\author{
Efeito do tamanho da amostra nos parâmetros cinéticos de \\ alimentos volumosos e concentrados por meio de um sistema de \\ produção de gases in vitro semi-automatizado
}

\author{
Mariane Moreno Ferro ${ }^{1 *}$; Luciano da Silva Cabral²; Livia Vieira de Barros ${ }^{2}$; \\ Claudio Vieira de Araujo ${ }^{3}$; Nelcino Francisco de Paula ${ }^{2}$
}

\begin{abstract}
This study aimed to evaluate the effect of different amounts of incubated samples on the kinetic parameters of in vitro fermentation of roughage and concentrated food used for feeding ruminants. Samples were prepared using 200,300, 400, and $500 \mathrm{mg}$ of air-dried roughage and concentrated sample, ground to $1 \mathrm{~mm}$, and placed in $120 \mathrm{~mL}$ glass flasks. Next, inoculum and McDougal solution were added, and the readings were obtained using a semi-automated pressure transducer up to $96 \mathrm{~h}$ after the beginning of the incubations. Gas production of the non-fibrous fraction increased linearly $(P<0.05)$ for sugarcane, Marandu grass silage, corn silage, dried corn distillers' grains with solubles, dried brewer's yeast, bean residue, wet brewer's grains, sunflower meal, and Jatropha meal; quadratically $(P<0.05)$ for Napier grass silage and cottonseed meal; and cubically $(P<0.05)$ for castor meal and soybean meal. The degradation rate of the non-fibrous fraction reduced linearly $(P<0.05)$ for sugarcane, Napier grass silage, and castor meal; quadratically $(P<0.05)$ for Marandu grass silage; and cubically $(P<0.05)$ for corn silage, soybean meal, dried corn distillers' grains with solubles, bean residue, and cottonseed meal. Gas production of the fibrous fraction increased linearly $(P<0.05)$ for Napier grass silage, Marandu grass silage, corn silage, dried corn distillers' grains with solubles, bean residue, wet brewer's grain, cottonseed meal, and sunflower meal; quadratically $(<0.05)$ for Jatropha meal; and cubically $(P<0.05)$ for sugarcane, castor meal, and soybean meal. The degradation rate of the fibrous fraction increased linearly $(P<0.05)$ for Napier grass silage, dried corn distillers' grains with solubles, dried brewer's yeast, wet brewer's grains; quadratically $(P<0.05)$ for corn silage and castor meal; and cubically $(P<$ $0.05)$ for sugarcane, Marandu grass silage, and bean residue. The lag time reduced linearly $(P<0.05)$ for castor meal and dried corn distillers' grains with solubles; quadratically $(P<0.05)$ for Napier grass silage; and cubically $(P<0.05)$ for sugarcane, Marandu grass silage, corn silage, soybean meal, bean residue, cottonseed meal, sunflower meal, and Jatropha meal. Thus, our findings suggest that the kinetic parameters of in vitro fermentation were affected as a function of the amount of incubated sample.
\end{abstract}

Key words: Digestion. Headspace. Lag time. Degradation rate. Gas production.

1 Dr ${ }^{\mathrm{a}}$ em Ciência Animal, Universidade Federal de Mato Grosso, UFMT, Cuiabá, MT, Brasil. E-mail: mmf_zootecnia@yahoo. com.br

2 Profs., UFMT, Cuiabá, MT, Brasil. E-mail: lucianoufmt@gmail.com; nelcinodepaula@hotmail.com; liviavieiradebarros@ gmail.com

3 Prof., UFMT, Sinop, MT, Brasil. E-mail: cvaufmt@gmail.com

"Author for correspondence 


\section{Resumo}

Objetivou-se com este trabalho avaliar o efeito de diferentes quantidades de amostras incubadas sobre os parâmetros cinéticos de fermentação in vitro de alimentos concentrados e volumosos disponíveis para alimentação de ruminantes. O preparo das amostras foi realizado utilizando 200, 300, 400 e 500 mg de amostra seca ao ar, moída a $1 \mathrm{~mm}$, alocadas em frascos de vidro com capacidade de $120 \mathrm{~mL}$, e adicionados inóculo e solução McDougal, seguidos das leituras, por meio de um transdutor de pressão semi-automatizado, até 96 horas após o inicio das incubações. A produção de gases da fração nãofibrosa apresentou comportamento linear crescente $(\mathrm{P}<0,05)$ para a cana-de-açúcar, silagem de capim marandu, silagem de milho, grão seco da destilaria do milho, resíduo de cervejaria desidratado, resíduo de feijão, resíduo úmido de cervejaria, torta de girassol e farelo de pinhão manso, quadrático $(\mathrm{P}<0,05)$ para silagem de capim napier e torta de algodão, e cúbico $(\mathrm{P}<0,05)$ para farelo de mamona e farelo de soja. A taxa de degradação da fração não-fibrosa apresentou redução linear $(\mathrm{P}<0,05)$ para a canade-açúcar, silagem de capim napier e farelo de mamona, quadrático $(\mathrm{P}<0,05)$ para a silagem de capim marandu, e cúbico $(\mathrm{P}<0,05)$ para a silagem de milho, farelo de soja, grão seco da destilaria do milho, resíduo de feijão e torta de algodão. A produção de gases da fração fibrosa apresentou comportamento linear crescente $(\mathrm{P}<0,05)$ para a silagem de capim napier, silagem de capim marandu, silagem de milho, grão seco da destilaria do milho, resíduo de feijão, resíduo úmido de cervejaria, torta de algodão e torta de girassol, quadrático $(\mathrm{P}<0,05)$ para farelo de pinhão manso, e cúbico $(\mathrm{P}<0,05)$ para a cana-de-açúcar, farelo de mamona, farelo de soja. A taxa de degradação da fração fibrosa apresentou comportamento linear decrescente $(\mathrm{P}<0,05)$ para a silagem de capim napier, grão seco da destilaria do milho, resíduo de cervejaria desidratado, resíduo úmido de cervejaria, quadrático $(\mathrm{P}<0,05)$ para a silagem de milho, farelo de mamona, e cúbico $(\mathrm{P}<0,05)$ para cana-de-açúcar, silagem de capim marandu e resíduo de feijão. O lag time apresentou redução linear $(\mathrm{P}<0,05)$ para o farelo de mamona e grão seco da destilaria do milho, quadrático $(\mathrm{P}<0,05)$ para a silagem de capim napier, e cúbico $(\mathrm{P}<0,05)$ para cana-de-açúcar, silagem de capim marandu, silagem de milho, farelo de soja, resíduo de feijão, torta de algodão, torta de girassol e farelo de pinhão manso. Os parâmetros cinéticos de fermentação in vitro foram afetados em função da quantidade de amostra incubada.

Palavras-chave: Digestão. Headspace. Lag time. Taxa de degradação. Produção de gases

\section{Introduction}

The nutritional value of ruminant feed is estimated using dynamic digestion models. The nutritive value of a food depends on several factors, including its chemical composition and nutrient utilization by animals, since nutrient utilization in ruminant animals depends on the symbiotic association with ruminal microbiota (Santo et al., 2017). Thus, assessing the ruminal degradation dynamics of several foods is fundamental for determining the adequacy of diets in relation to the ratios of food fractions, as well as the digestion rate and losses due to ruminal fermentation (Goes et al., 2010).

An efficient laboratory method for determining the nutritional value of food should be reproducible and have a good correlation with parameters measured in vivo. The in vitro methods are less expensive, more efficient, and allow more precise maintenance of experimental conditions than the in vivo assays (Getachew, Blummel, Makkar, \& Becker, 1998), and hence are preferably used to measure the rate and extent of nutrient degradation in ruminants (Groot, Cone, Willians, Debersaques, \& Lantinga, 1996).

Although pressure transducers a relatively simple and inexpensive technique have been used to estimate the fermentation kinetics of food or diets for ruminant animals, many factors can affect the gas production profile of foods that need to be assessed. These factors include medium agitation during fermentation; inoculum origin, conservation, and manipulation; gas production measurement system; atmospheric pressure; sample preparation and size; and buffer amount and composition (Rymer, Huntington, Williams, \& Givens, 2005). 
Methodologically, the amount of sample used in different studies ranges from 100 to $1000 \mathrm{mg}$ (Goering \& Van Soest, 1970; Menke et al., 1979; Theodorou, Williams, Dhanoa, Mcallan, \& France, 1994). Small amounts of sample may increase experimental errors owing to heterogeneous weighing during sampling, as observed in the study of Menke et al. (1979), who indicated that low sample weight was a critical point in the gas production method. However, when high amounts of samples are used, the system (buffer) should be able to buffer short-chain fatty acids produced, and the accumulated pressure should not be excessively high to adversely affect the fermentation and production of gases (Rymer et al., 2005).

In general, the total amount of gases produced has been found to linearly increase with an increase in the amount of incubated sample (Theodorou et al., 1994); however, when the headspace is reduced by using flasks of equal volume, the sensitivity of the system to detect the production of small volumes of gases - usually derived from the soluble fractions of food might likely be high at the initial incubation times. This may influence the degradation rate and lag time estimated for the incubated samples. Hence, standardizing the amount of sample for in vitro gas measurement systems becomes necessary when semi-automated systems are used to allow the precise and accurate estimation of the kinetic parameters that can be used regardless of the food analyzed.

This study aimed to evaluate the effect of different amounts of incubated samples on the kinetic parameters of in vitro fermentation of roughage and concentrated food used for feeding ruminants.

\section{Material and Methods}

\section{Characterization and chemical analysis of food}

The food used for analysis was chosen owing to its high availability and frequency of use in ruminant nutrition in Mato Grosso, Brazil. The roughage foods were sugarcane in natura, Napier grass silage, corn silage, and Marandu grass silage; the concentrated foods were dried corn distillers' grains with solubles, soybean meal, castor meal, dried brewer's yeast, bean residue, wet brewer's grains, cottonseed meal, sunflower meal, and Jatropha meal. Food was sampled from different regions (Sinop, Cuiabá, and Rondonópolis) from Mato Grosso, Brazil. Some regional foods could be used for making only one sample, whereas three samples were obtained for less regionalized food, which was homogenized to form a composite sample. The incubations were performed at the Laboratory of Animal Nutrition of the Federal University of Mato Grosso Campus Cuiabá, MT, Brazil.

All samples were analyzed according to the standard analysis procedures of the Brazilian National Institute of Science and Technology on Animal Science (INCT-CA; Detmann et al., 2012). The samples of roughage foods were pre-dried in a convection oven at $55{ }^{\circ} \mathrm{C}$ for $72 \mathrm{~h}$ to obtain dry air samples (INCT-CA G-001/1). Next, all the feeds were oven-dried at $105{ }^{\circ} \mathrm{C}$ to determine the final dry matter (INCT-CA G-003/1). They were then milled using a $1 \mathrm{~mm}$ sieve to analyze crude protein (INCTCA N-001/1), mineral matter (INCT-CA M-001/1), ether extract (INCT-CA G-004/1), neutral detergent fiber (INCT-CA F-002/1), and acid detergent fiber (INCT-CA F-004/1). Total carbohydrates (TCs) were calculated according to Sniffen, O'Connor, Van Soest, Fox and Russell (1992). The indigestible neutral detergent fiber (iNDF) of the food was obtained using in situ incubation for $240 \mathrm{~h}$ (Casali et al., 2008), followed by analysis of NDF. Potentially fermentable organic matter ( $\mathrm{pFOM})$ was estimated using the equation: $1000-(\mathrm{MM}+$ $\mathrm{EE}+\mathrm{iNDF}$ ), and the fraction of total potentially digestible carbohydrates (tpDCs) was estimated using the equation: NFC $* 0.98+$ NDFap - iNDF. The chemical composition of food is described in Table 1. 


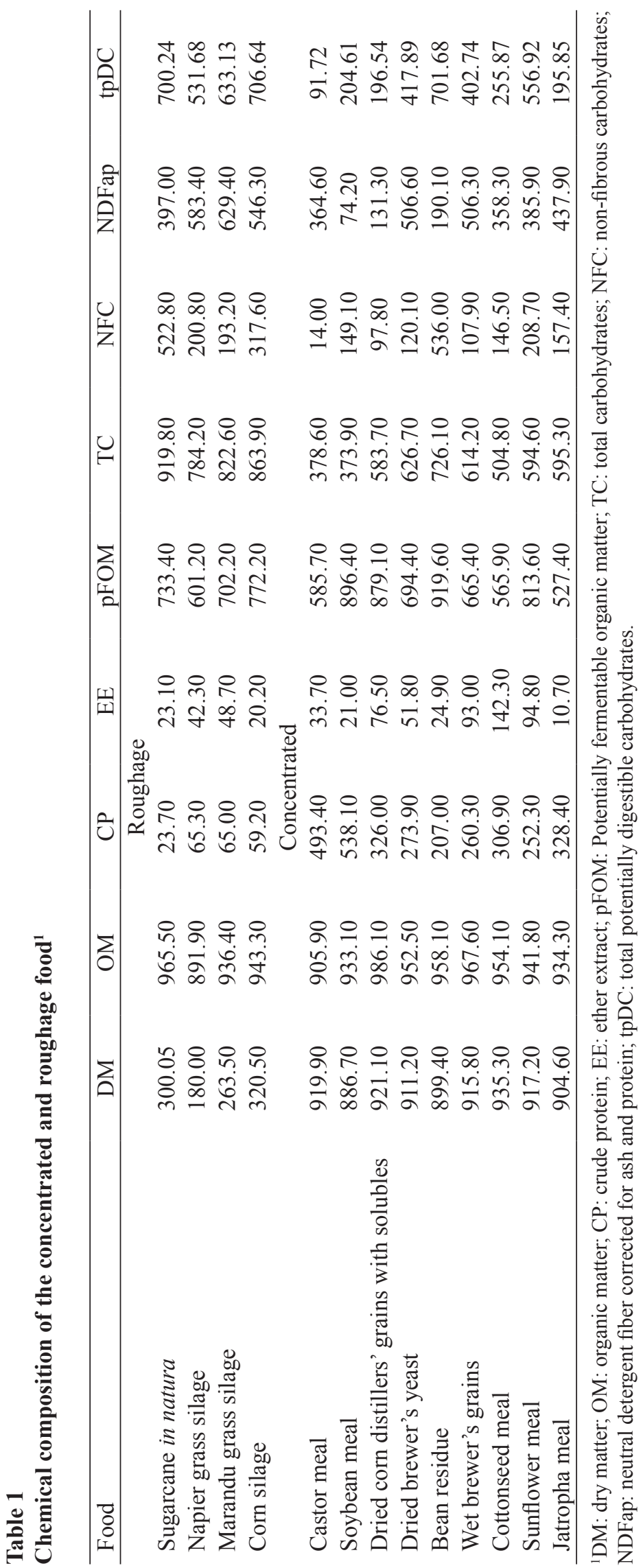


Gas production and kinetic parameters of ruminal fermentation

Samples for the in vitro incubations were prepared using the gas production technique by using 200, 300, 400, and $500 \mathrm{mg}$ of air-dried sample ground to $1 \mathrm{~mm}$. The samples were then placed in $120 \mathrm{~mL}$ amber glass flasks. To the flasks, $20 \mathrm{~mL}$ of $16 \mathrm{~mL}$ McDougal buffer solution $+4 \mathrm{~mL}$ inoculum, $30 \mathrm{~mL}$ of $24 \mathrm{~mL}$ McDougal buffer solution +6 $\mathrm{mL}$ inoculum, $40 \mathrm{~mL}$ of $32 \mathrm{~mL}$ McDougal buffer $+8 \mathrm{~mL}$ inoculum, or $50 \mathrm{~mL}$ of $40 \mathrm{~mL}$ McDougal buffer solution $+10 \mathrm{~mL}$ inoculum was added. The McDougal buffer solution was previously reduced with $\mathrm{CO}_{2}$ ( $\mathrm{pH}$ 6.9-7.0), according to McDougal (1949). The inoculum was obtained from a fistulated dairy cow fed $2 \mathrm{~kg}$ of concentrate per day.

Immediately, the flasks were covered with rubber cap and aluminum seal and placed in a water bath at $39{ }^{\circ} \mathrm{C}$ and $45 \mathrm{rpm}$. Pressure readings (psi, pressure per square inch) were obtained using a pressure transducer (Datalogger Pressure ${ }^{\circledR}$ ) at 2, 4, 6, 8, 10, $12,24,48,72$, and $96 \mathrm{~h}$. The volume of gases from rumen liquid and buffer solution was measured by incubating two flasks without a sample (white). Thus, for each reading time, the volume of gases from the flasks with sample was subtracted from that of the flasks without sample.

\section{Statistical analysis}

The sum of the volume of gases for each reading time was used to establish the cumulative production curves of gases. Conversion from psi to $\mathrm{mL}$ was performed using the regression equation ( $\mathrm{Y}=\mathrm{a} \pm$ $\mathrm{bx}$ ), in which the coefficient "b" of the equation enabled correction and transformation of pressure (psi) into the volume of gases $(\mathrm{mL})$ corrected for barometric pressure of the day. For this, a known volume of gases was injected into flasks kept under the same conditions as those of incubated samples. For each relation of the sample tested, a curve was generated according to the pressures corresponding to the injected volumes $(20,30,40$, and $50 \mathrm{~mL})$, and the same measures were used to obtain the regression equation between gas pressure and volume.

The kinetics of cumulative gas production was analyzed using the logistic bi-compartmental model of Schofield, Pitt and Pell (1994): V(t) $=$ Vfl/ $\left(1+\exp \left(2-4 * c 1^{*}(\mathrm{~T}-\mathrm{L})\right)\right)+\mathrm{Vf} 2 /(1+\exp (2-$ $4 * c 2 *(\mathrm{~T}-\mathrm{L})))$, where $\mathrm{V}(\mathrm{t})$ is the cumulative volume at time $t$; Vfl, the final volume of gases of the fast degradation fraction; $c 1\left(\mathrm{~h}^{-1}\right)$, the degradation rate of the fast degradation fraction; Vf2, the final volume of gases of the slow degradation fraction; $c 2\left(\mathrm{~h}^{-1}\right)$, the degradation rate of the slow degradation fraction; L, the lag time; and T, time (h).

The studied variables were analyzed using the MIXED procedure of SAS, version 9.2. Pearson's correlation coefficient analyses were performed between the chemical composition of the food and the total gas production as a function of the different amounts of incubated sample. The parameters were analyzed using $F$ test in ANOVA. The LSMEANS option was used to generate the individual means for each treatment. After the quantitative factors were obtained, orthogonal contrasts were used for specifically partitioning the effects into linear, quadratic, or cubic. The effects were considered significant when $P<0.05$.

\section{Results and Discussion}

Correlation coefficients between the chemical composition of food and total gas production as a function of the different amounts of incubated samples

The total gas production of the foods as a function of the different amounts of incubated sample showed a significant correlation $(P<0.05)$ of $0.7667,0.6305,0.7405$, and 0.7449 with $\mathrm{pFOM}$, TCs, tpDCs, and NFCs, respectively. No significant effect $(P>0.05)$ was noted for the correlation between total gas production and organic matter $(\mathrm{OM})$, crude protein $(\mathrm{CP})$, ether extract $(\mathrm{EE})$, and neutral detergent fiber corrected for ash and protein (NDFap), which averaged 0.3914, $-0.5204,-0.3638$, and 0.1493 , respectively (Table 2 ). 
Table 2

Correlation coefficients between the chemical composition of the food and total gas production as a function of the different amounts of incubated samples

\begin{tabular}{lcccc}
\hline Variables $^{1}$ & PGT200 & PGT300 & PGT400 & PGT500 \\
\hline OM & 0.3887 & 0.3982 & 0.3839 & 0.3951 \\
pFOM & $0.7856^{*}$ & $0.7703^{*}$ & $0.7349^{*}$ & $0.7760^{*}$ \\
CP & -0.4943 & -0.4989 & -0.5431 & -0.5456 \\
EE & -0.3869 & -0.3683 & -0.3924 & -0.3079 \\
BC & $0.6106^{*}$ & $0.6122^{*}$ & $0.6572^{*}$ & $0.6421^{*}$ \\
tpDC & $0.7267^{*}$ & $0.7108^{*}$ & $0.7366^{*}$ & $0.7880^{*}$ \\
NFC & $0.7449^{*}$ & $0.7657^{*}$ & $0.7638^{*}$ & $0.7053^{*}$ \\
NDFap & -0.1768 & -0.2070 & -0.1418 & -0.0716 \\
\hline
\end{tabular}

${ }^{1} \mathrm{DM}$ : dry matter; OM: organic matter; CP: crude protein; EE: ether extract; pFOM: Potentially fermentable organic matter; TC: total carbohydrates; NFC: non-fibrous carbohydrates; NDFap: neutral detergent corrected for ash and protein; tpDC: potentially digestible carbohydrates.

Getachew, Robinson, DePeters and Taylor (2004) evaluated the correlation between the chemical composition of different foods and the extent of gas production; their results were considerably similar to ours. They found that the protein content and available food protein were correlated negatively, whereas the NFC content was correlated positively with gas production at 6,24 , and $48 \mathrm{~h}$ of incubation.

\section{The in vitro kinetic parameters}

\section{Roughage feeds}

Gas production from the degradation of NFCs showed an linear increasing effect $(P<0.05)$ for in natura sugarcane, Marandu grass silage, and corn silage, whereas quadratic effect $(P<0.05)$ for Napier grass silage, according to the different amounts of incubated sample (Table 3 ). The degradation rate of NFC fraction showed a linear effect $(P<0.05)$ for in natura sugarcane and Napier grass silage, whereas a quadratic effect $(P<0.05)$ for Marandu grass silage and a cubic effect $(P<0.05)$ for corn silage.

Gas production from the degradation of fibrous carbohydrates showed a cubic effect $(P<0.05)$ for in natura sugarcane and an increasing linear effect $(P<0.05)$ for Napier grass silage, Marandu grass silage, and corn silage, according to the different amounts of incubated sample. The degradation rate of the NFC fraction showed a cubic effect $(P$ $<0.05$ ) for in natura sugarcane and Marandu grass silage, whereas a decreasing linear effect for Napier grass silage and a quadratic effect $(P<0.05)$ for corn silage (Table 3 ).

The total gas production showed a cubic effect ( $P$ $<0.05$ ) for in natura sugarcane, Marandu grass silage, and corn silage, whereas a linear effect $(P<0.05)$ for Marandu grass silage as a function of the different amounts of incubated sample. The lag time was also affected by the different amounts of incubated sample, with a quadratic effect $(P<0.05)$ for Napier grass silage and a cubic effect $(P<0.05)$ for in natura sugarcane, Marandu grass silage, and corn silage (Table 3).

Similar to our results, Campos, Lanna, Bose and Boin (2000) varied the amount of incubated alfalfa hay between 50 and $110 \mathrm{mg}$ and observed a quadratic behavior for gas production as a function of the amount of incubated sample. They also observed an alteration in the final $\mathrm{pH}$, which was reduced when larger amounts of incubated samples were used after $48 \mathrm{~h}$ of incubation and cautioned against the use of large amounts of incubated sample as the reduction of $\mathrm{pH}$ may change the fermentation process once the buffer solution has no effect on the buffering of the medium.

In contrast, Theodorou et al. (1994), who used roughage amounts ranging from 200 to $2000 \mathrm{mg}$ 
incubated with $100 \mathrm{~mL}$ of mixed culture in $125 \mathrm{~mL}$ bottles, observed a linear increase in the total gas production; however, no effect was noted on the lag time and degradation rates.

Gas production depending on available headspace showed an increasing linear effect $(P$ $<0.05)$ for in natura sugarcane and Napier grass silage and a quadratic effect $(P<0.05)$ for Marandu grass silage and corn silage as a function of the amount of incubated sample. The production of gases per milligram of incubated sample showed a linear reduction $(P<0.05)$ for in natura sugarcane, Napier grass silage, and corn silage and a quadratic effect $(P<0.05)$ for Marandu grass silage. Gas production as a function of the amount of tpDCs and $\mathrm{pFOM}$ showed a quadratic effect $(P<0.05)$ for in natura sugarcane and an increasing linear effect for Napier grass silage, Marandu grass silage, and corn silage as a function of the amount of incubated sample (Table 4).

Table 3

Production of gases from the fraction of non-fibrous carbohydrates and fibrous carbohydrates, fraction degradation rate of non-fibrous carbohydrates and fibrous carbohydrate, total gas production and lag time as a function of the amount of incubated sample from roughage foods

\begin{tabular}{|c|c|c|c|c|c|c|c|c|}
\hline \multirow{2}{*}{ Food } & \multicolumn{4}{|c|}{ Amount of incubated sample (mg) } & \multirow{2}{*}{$\mathrm{SEM}^{1}$} & \multicolumn{3}{|c|}{$P$ value* } \\
\hline & 200 & 300 & 400 & 500 & & Linear & Quadratic & Cubic \\
\hline \multicolumn{9}{|c|}{ Gas production from degradation of the non-fibrous carbohydrate fraction $(\mathrm{mL})$} \\
\hline Sugarcane in natura & 17.36 & 25.64 & 31.76 & 38.62 & 0.36 & $<0.0001$ & 0.1212 & 0.1497 \\
\hline Napier grass silage & 16.56 & 23.93 & 34.51 & 44.53 & 0.47 & $<0.0001$ & 0.0489 & 0.1507 \\
\hline Marandu grass silage & 20.22 & 29.42 & 38.54 & 41.42 & 1.22 & 0.0002 & 0.0615 & 0.3248 \\
\hline Corn silage & 27.30 & 37.00 & 37.42 & 40.87 & 1.54 & 0.0040 & 0.1136 & 0.1497 \\
\hline \multicolumn{9}{|c|}{ Degradation rate of the non-fibrous carbohydrate fraction $\left(\mathrm{h}^{-1}\right)$} \\
\hline Sugarcane in natura & 0.3492 & 0.3140 & 0.2109 & 0.2326 & 0.01 & 0.0058 & 0.2065 & 0.0845 \\
\hline Napier grass silage & 0.0876 & 0.0715 & 0.0580 & 0.0398 & 0.00 & 0.0010 & 0.8069 & 0.7055 \\
\hline Marandu grass silage & 0.0772 & 0.0596 & 0.0613 & 0.0588 & 0.00 & 0.0056 & 0.0265 & 0.0773 \\
\hline Corn silage & 0.0775 & 0.0717 & 0.0595 & 0.1485 & 0.00 & $<0.0001$ & $<0.0001$ & 0.0009 \\
\hline \multicolumn{9}{|c|}{ Gas production from degradation of the fibrous carbohydrate fraction $(\mathrm{mL})$} \\
\hline Sugarcane in natura & 41.60 & 56.82 & 72.81 & 78.93 & 0.73 & $<0.0001$ & 0.0035 & 0.0322 \\
\hline Napier grass silage & 22.46 & 30.35 & 37.32 & 39.05 & 1.98 & 0.0031 & 0.1953 & 0.6515 \\
\hline Marandu grass silage & 33.92 & 40.39 & 53.55 & 67.83 & 1.83 & 0.0002 & 0.1006 & 0.5343 \\
\hline Corn silage & 29.69 & 43.22 & 67.72 & 89.48 & 2.33 & $<0.0001$ & 0.1534 & 0.2604 \\
\hline \multicolumn{9}{|c|}{ Degradation rate of the fibrous carbohydrate fraction $\left(\mathrm{h}^{-1}\right)$} \\
\hline Sugarcane in natura & 0.0239 & 0.0236 & 0.0211 & 0.0203 & 0.00 & 0.0004 & 0.5154 & 0.0360 \\
\hline Napier grass silage & 0.0197 & 0.0200 & 0.0174 & 0.0164 & 0.00 & 0.0097 & 0.3202 & 0.1626 \\
\hline Marandu grass silage & 0.0216 & 0.0173 & 0.0187 & 0.0189 & 0.00 & 0.0038 & 0.0009 & 0.0036 \\
\hline Corn silage & 0.0205 & 0.0183 & 0.0167 & 0.0203 & 0.00 & 0.3246 & 0.0021 & 0.0636 \\
\hline \multicolumn{9}{|c|}{ Total gas production $(\mathrm{mL})$} \\
\hline Sugarcane in natura & 58.96 & 82.46 & 104.58 & 117.56 & 0.91 & $<0.0001$ & 0.0046 & 0.1312 \\
\hline Napier grass silage & 39.02 & 54.28 & 71.83 & 83.58 & 1.74 & $<0.0001$ & 0.37143 & 0.3583 \\
\hline Marandu grass silage & 54.14 & 69.82 & 92.10 & 109.25 & 1.35 & $<0.0001$ & 0.6154 & 0.1253 \\
\hline Corn silage & 56.99 & 80.23 & 105.14 & 130.35 & 1.07 & $<0.0001$ & 0.4117 & 0.7897 \\
\hline \multicolumn{9}{|c|}{ Lag time (hours) } \\
\hline Sugarcane in natura & 3.63 & 3.57 & 2.16 & 2.85 & 0.14 & 0.0044 & 0.0614 & 0.0059 \\
\hline Napier grass silage & 17.01 & 14.56 & 12.52 & 3.39 & 0.93 & 0.0005 & 0.0237 & 0.1484 \\
\hline Marandu grass silage & 14.31 & 0.1057 & 13.10 & 11.47 & 0.68 & 0.1230 & 0.1999 & 0.0272 \\
\hline Corn silage & 14.00 & 12.72 & 5.80 & 9.95 & 0.11 & $<0.0001$ & $<0.0001$ & $<0.0001$ \\
\hline
\end{tabular}

${ }^{1} \mathrm{SEM}$ : standard error of the mean; $* P$-value: $P<0.05$. 
Table 4

Gas production as a function of available headspace, amount of sample $\left(\mathrm{mg}^{-1}\right)$, amount of potentially digestible carbohydrates (tpDC), and potentially fermentable organic matter (pFOM) incubated with roughage foods

\begin{tabular}{|c|c|c|c|c|c|c|c|c|}
\hline \multirow{2}{*}{ Food } & \multicolumn{4}{|c|}{ Amount of incubated sample (mg) } & \multirow{2}{*}{ SEM $^{1}$} & \multicolumn{3}{|c|}{$P$ value* } \\
\hline & 200 & 300 & 400 & 500 & & Linear & Quadratic & Cubic \\
\hline \multicolumn{9}{|c|}{ Gas production by available headspace } \\
\hline Sugarcane in natura & 0.58 & 0.91 & 1.30 & 1.67 & 0.01 & $<0.0001$ & 0.1309 & 0.1962 \\
\hline Napier grass silage & 0.39 & 0.60 & 0.89 & 1.19 & 0.02 & $<0.0001$ & 0.1440 & 0.4761 \\
\hline Marandu grass silage & 0.54 & 0.77 & 1.15 & 1.56 & 0.01 & $<0.0001$ & 0.0065 & 0.2286 \\
\hline Corn silage & 0.57 & 0.89 & 1.31 & 1.86 & 0.01 & $<0.0001$ & 0.0008 & 0.6898 \\
\hline \multicolumn{9}{|c|}{ Gas production $\mathrm{mg}^{-1}$ of incubated sample } \\
\hline Sugarcane in natura & 0.29 & 0.27 & 0.26 & 0.23 & 0.00 & $<0.0001$ & 0.2546 & 0.1441 \\
\hline Napier grass silage & 0.19 & 0.18 & 0.17 & 0.16 & 0.00 & 0.0188 & 0.8687 & 0.3449 \\
\hline Marandu grass silage & 0.27 & 0.23 & 0.23 & 0.21 & 0.00 & 0.0014 & 0.0428 & 0.0891 \\
\hline Corn silage & 0.28 & 0.26 & 0.26 & 0.26 & 0.00 & 0.0123 & 0.1261 & 0.5871 \\
\hline \multicolumn{9}{|c|}{ Gas production $\mathrm{mg}^{-1}$ of tpDC } \\
\hline Sugarcane in natura & 0.08 & 0.11 & 0.14 & 0.16 & 0.00 & $<0.0001$ & 0.0046 & 0.1312 \\
\hline Napier grass silage & 0.07 & 0.10 & 0.13 & 0.15 & 0.00 & $<0.0001$ & 0.3713 & 0.3583 \\
\hline Marandu grass silage & 0.08 & 0.11 & 0.14 & 0.17 & 0.00 & $<0.0001$ & 0.6154 & 0.1253 \\
\hline Corn silage & 0.08 & 0.11 & 0.14 & 0.18 & 0.00 & $<0.0001$ & 0.4117 & 0.7897 \\
\hline \multicolumn{9}{|c|}{ Gas production $\mathrm{mg}^{-1}$ of $\mathrm{pFOM}$} \\
\hline Sugarcane in natura & 0.08 & 0.11 & 0.14 & 0.16 & 0.00 & $<0.0001$ & 0.0046 & 0.1312 \\
\hline Napier grass silage & 0.06 & 0.09 & 0.11 & 0.13 & 0.00 & $<0.0001$ & 0.3713 & 0.3583 \\
\hline Marandu grass silage & 0.07 & 0.09 & 0.13 & 0.15 & 0.00 & $<0.0001$ & 0.6154 & 0.1253 \\
\hline Corn silage & 0.07 & 0.10 & 0.13 & 0.16 & 0.00 & $<0.0001$ & 0.4117 & 0.7897 \\
\hline
\end{tabular}

${ }^{1}$ SEM: standard error of the mean; $* P$-value: $P<0.05$.

\section{Concentrated feeds}

Gas production from the degradation of NFCF showed a linear increasing effect $(P<0.05)$ for dried corn distillers' grains with solubles, dried brewer's yeast, bean residue, wet brewer's grains, sunflower meal, and Jatropha meal; quadratic effect $(P<0.05)$ for cottonseed meal; and cubic effect $(P<0.05)$ for castor meal and soybean meal as a function of the amount of incubated sample. The degradation rate of NFC fraction showed a linear decreasing effect $(P<$ 0.05 ) for castor meal and a cubic effect for soybean meal, dried corn distillers' grains with solubles, bean residue, and cottonseed meal, whereas no significant effect $(P>0.05)$ for dried corn distillers' grains with solubles, wet brewer's grain, sunflower meal, and Jatropha meal as a function of the amount of incubated sample (Table 5).
Gas production from the degradation of fibrous carbohydrate fraction showed a linear increasing effect $(P<0.05)$ for dried corn distillers' grains with solubles, bean residue, wet brewer's grains, cottonseed meal, and sunflower meal; quadratic effect $(P<0.05)$ for Jatropha meal; and cubic effect $(P<0.05)$ for castor meal and soybean meal as a function of the amount of incubated sample. The degradation rate of fibrous carbohydrate fraction showed a linear decreasing effect $(P<0.05)$ for dried corn distillers' grains with solubles, dried brewer's yeast, and wet brewer's grains; quadratic effect $(P<0.05)$ for castor meal; and cubic effect for bean residue. However, the amount of incubated sample had no significant effect $(P>0.05)$ on the degradation rate of fibrous carbohydrate fraction for soybean meal, cottonseed meal, sunflower meal, and Jatropha meal (Table 5). 
The total gas production showed a linear increasing effect $(P<0.05)$ for almost all concentrated foods evaluated, except for Jatropha meal, which showed a cubic effect $(P<0.05)$ as a function of the different amounts of incubated sample. The lag time was also influenced as a function of the different amounts of incubated sample, with a linear decreasing effect for castor meal and dried corn distillers' grains with solubles and a cubic effect $(P<0.05)$ for soybean meal, bean residue, cottonseed meal, sunflower meal, and Jatropha meal.

Ramin and Huhtanen (2012) evaluated the effect of different amounts of samples (300, 600, 900, and $1200 \mathrm{mg}$ ) incubated with $60 \mathrm{~mL}$ of substrate in $260 \mathrm{~mL}$ flasks and observed a linear reduction in the digestibility of the fractions as the amount of incubated sample increased. Such behavior was justified because of the saturation of the medium with volatile fatty acids, which reduced the $\mathrm{pH}$ and then precluded digestibility. Notably, in their study, the amount of buffered rumen fluid was the same for all treatments $(60 \mathrm{~mL})$; in contrast, in the present study, the buffered ruminal fluid varied according to the amount of incubated sample $(20,30,40$, and $50 \mathrm{~mL}$ ).

Cone and Van Gelder (1996) tested different concentrations of a corn by-product and found that, after $10 \mathrm{~h}$ of incubation, the medium was saturated when 700 and $900 \mathrm{mg}$ of corn by-product was incubated with $60 \mathrm{~mL}$ of mixed solution of ruminal liquid and buffer solution in a 1:2 ratio, unlike when 300 and $500 \mathrm{mg}$ of corn by-product was used, which led to the production of higher amounts of gases because they showed a more favorable medium for fermentation.

The production of gases depending on available headspace showed a linear increasing effect $(P<$ 0.05 ) for castor meal, soybean meal, dried brewer's yeast, cottonseed meal, and sunflower meal; quadratic effect $(P<0.05)$ for dried corn distillers' grains with solubles, bean residue, and wet brewer's grains; and cubic effect $(P<0.05)$ for Jatropha meal as a function of the amount of incubated sample. The production of gases per milligram of incubated sample showed a linear reduction $(P<0.05)$ for castor meal, soybean meal, dried corn distillers' grains with solubles, and bean residue; quadratic effect $(P<0.05)$ for wet brewer's grains; and nonsignificant effect $(P>0.05)$ for dried brewer's yeast and cottonseed meal. Gas production as a function of the amount of tpDCs and pFOM showed an increasing linear effect $(P<0.05)$ for almost all concentrated foods, except for Jatropha meal, which showed a quadratic effect $(P<0.05$; Table 6$)$. 


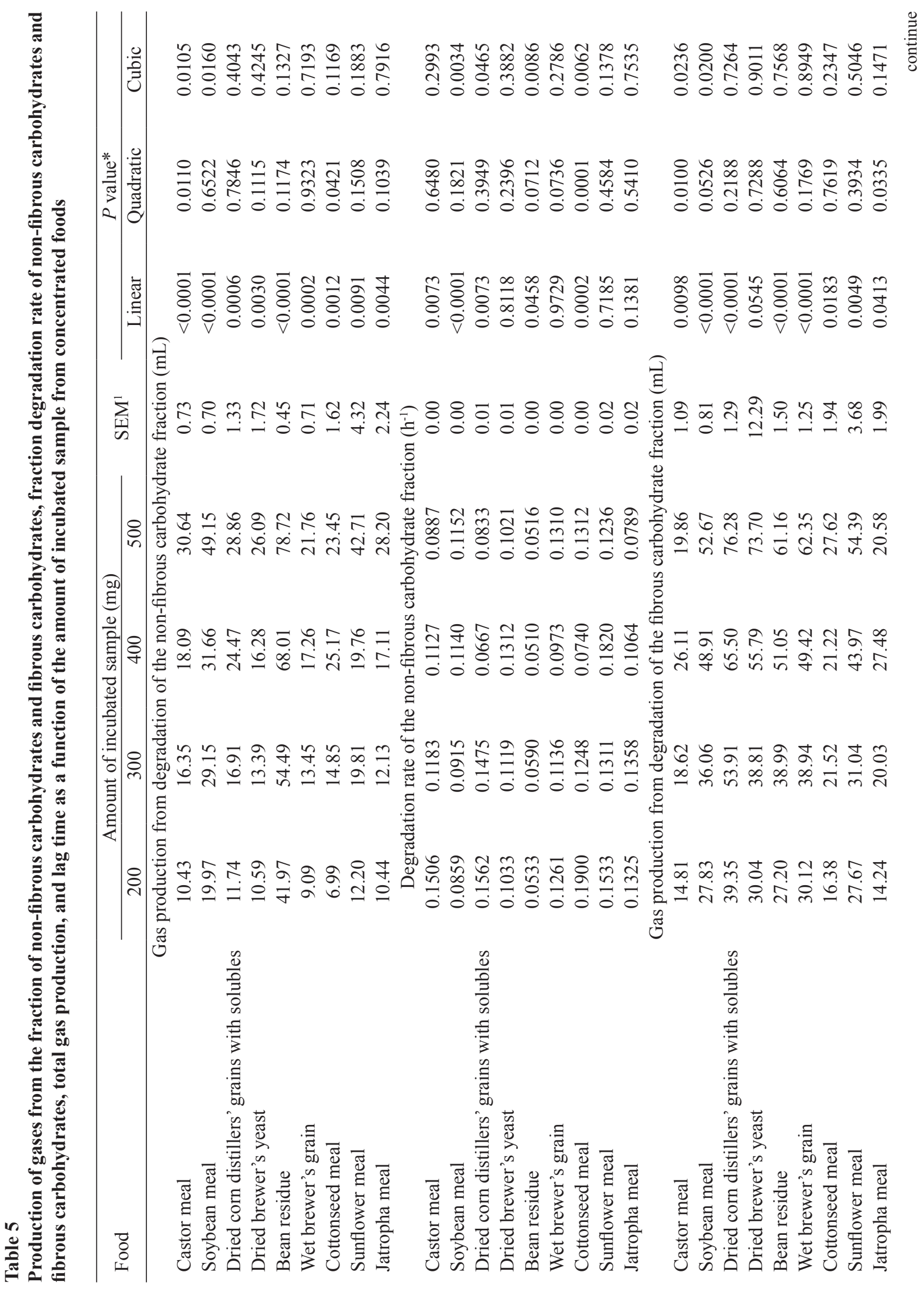




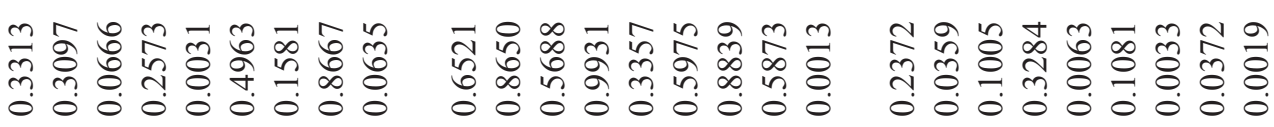

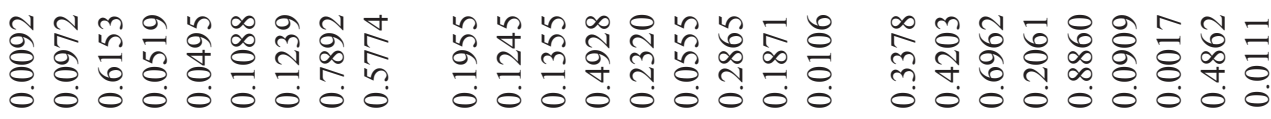

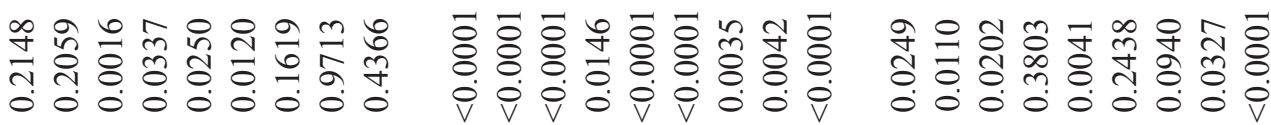

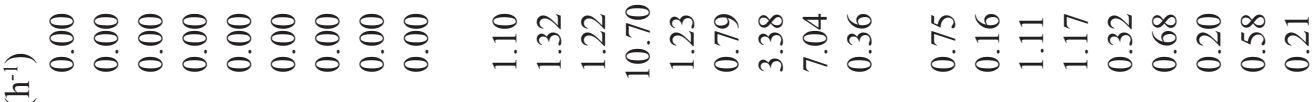

:

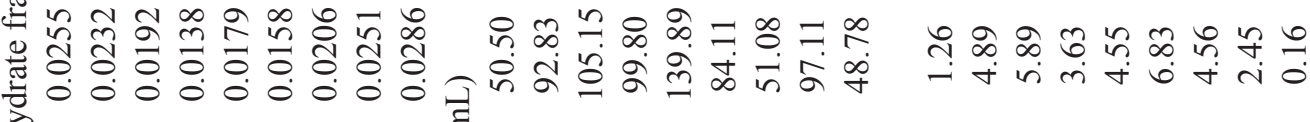

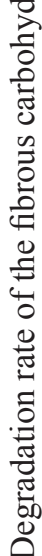

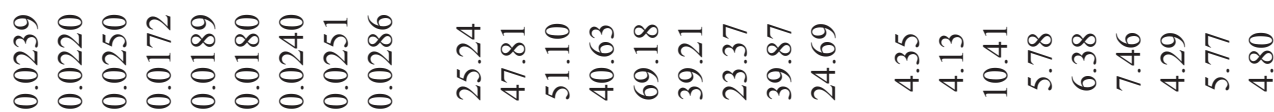

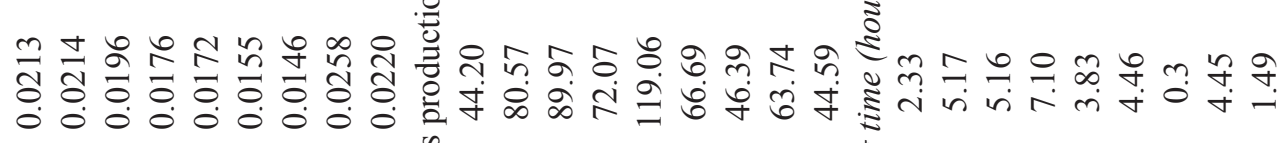

$\infty \bar{n} \infty$ 웅요 8

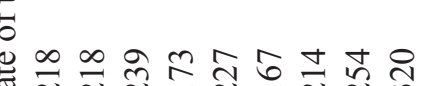

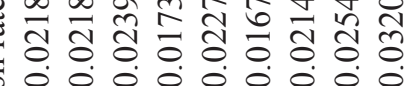
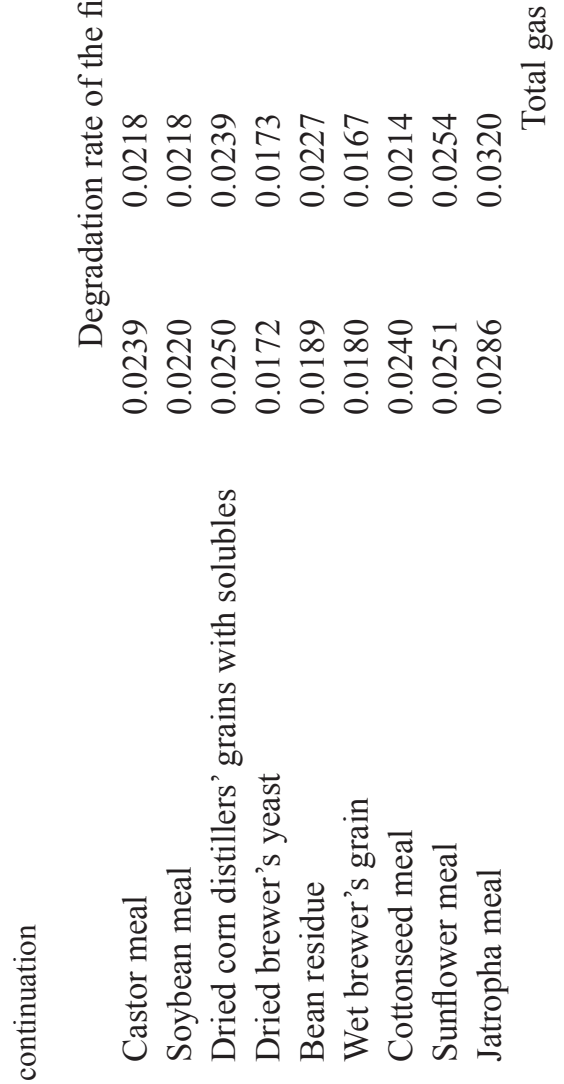

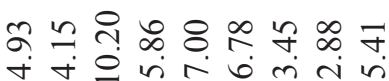

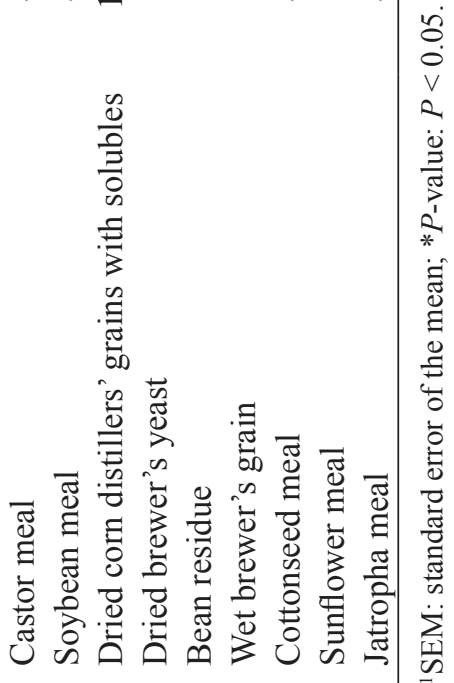


Table 6

Gas production as a function of available headspace, amount of sample $\left(\mathrm{mg}^{-1}\right)$, amount of potentially digestible carbohydrates (tpDC), and potentially fermentable organic matter (pFOM) incubated with concentrated foods

\begin{tabular}{|c|c|c|c|c|c|c|c|c|}
\hline \multirow[t]{2}{*}{ Food } & \multicolumn{4}{|c|}{$\begin{array}{c}\text { Amount of incubated } \\
\text { sample (mg) }\end{array}$} & \multirow[t]{2}{*}{$\mathrm{SEM}^{1}$} & \multicolumn{3}{|c|}{$P$ value* } \\
\hline & 200 & 300 & 400 & 500 & & Linear & Quadratic & Cubic \\
\hline \multicolumn{9}{|c|}{ Gas production by available headspace } \\
\hline Castor meal & 0.25 & 0.38 & 0.55 & 0.72 & 0.01 & $<0.0001$ & 0.3226 & 0.7431 \\
\hline Soybean meal & 0.47 & 0.72 & 1.00 & 1.32 & 0.01 & $<0.0001$ & 0.0878 & 0.9990 \\
\hline Dried corn distillers' grains with solubles & 0.51 & 0.78 & 1.12 & 1.50 & 0.01 & $<0.0001$ & 0.0263 & 0.7561 \\
\hline Dried brewer's yeast & 0.40 & 0.58 & 0.90 & 1.42 & 0.15 & 0.0078 & 0.3143 & 0.9378 \\
\hline Bean residue & 0.69 & 1.03 & 1.48 & 1.99 & 0.01 & $<0.0001$ & 0.0061 & 0.5718 \\
\hline Wet brewer's grain & 0.39 & 0.58 & 0.83 & 1.20 & 0.00 & $<0.0001$ & 0.0006 & 0.2496 \\
\hline Cottonseed meal & 0.23 & 0.40 & 0.58 & 0.72 & 0.04 & 0.0012 & 0.8300 & 0.8843 \\
\hline Sunflower meal & 0.39 & 0.56 & 0.79 & 1.38 & 0.09 & 0.0020 & 0.9930 & 0.5450 \\
\hline Jatropha meal & 0.24 & 0.35 & 0.55 & 0.69 & 0.00 & $<0.0001$ & 0.0291 & 0.0015 \\
\hline \multicolumn{9}{|c|}{ Gas production $\mathrm{mg}^{-1}$ of incubated sample } \\
\hline Castor meal & 0.12 & 0.11 & 0.11 & 0.10 & 0.00 & 0.0027 & 0.9867 & 0.6030 \\
\hline Soybean meal & 0.23 & 0.21 & 0.20 & 0.18 & 0.00 & 0.0005 & 0.4890 & 0.7630 \\
\hline Dried corn distillers' grains with solubles & 0.25 & 0.23 & 0.22 & 0.21 & 0.00 & 0.0009 & 0.5566 & 0.5199 \\
\hline Dried brewer's yeast & 0.20 & 0.17 & 0.18 & 0.19 & 0.02 & 0.9654 & 0.3258 & 0.8313 \\
\hline Bean residue & 0.34 & 0.31 & 0.29 & 0.27 & 0.00 & 0.0001 & 0.0680 & 0.1760 \\
\hline Wet brewer's grain & 0.19 & 0.17 & 0.16 & 0.16 & 0.00 & 0.0023 & 0.0182 & 0.7772 \\
\hline Cottonseed meal & 0.11 & 0.12 & 0.11 & 0.10 & 0.00 & 0.2399 & 0.3193 & 0.9779 \\
\hline Sunflower meal & 0.19 & 0.16 & 0.15 & 0.19 & 0.01 & 0.7287 & 0.1033 & 0.7319 \\
\hline Jatropha meal & 0.12 & 0.10 & 0.11 & 0.09 & 0.00 & 0.0001 & 0.3594 & 0.0014 \\
\hline \multicolumn{9}{|c|}{ Gas production $\mathrm{mg}^{-1}$ of tpDC } \\
\hline Castor meal & 0.27 & 0.38 & 0.48 & 0.55 & 0.01 & $<0.0001$ & 0.1955 & 0.6521 \\
\hline Soybean meal & 0.23 & 0.31 & 0.39 & 0.45 & 0.06 & $<0.0001$ & 0.1245 & 0.8650 \\
\hline Dried corn distillers' grains with solubles & 0.26 & 0.36 & 0.45 & 0.53 & 0.00 & $<0.0001$ & 0.1355 & 0.5688 \\
\hline Dried brewer's yeast & 0.09 & 0.12 & 0.17 & 0.23 & 0.02 & 0.0146 & 0.4928 & 0.9931 \\
\hline Bean residue & 0.09 & 0.13 & 0.16 & 0.19 & 0.00 & $<0.0001$ & 0.2320 & 0.3357 \\
\hline Wet brewer's grain & 0.09 & 0.13 & 0.16 & 0.20 & 0.00 & $<0.0001$ & 0.0555 & 0.5975 \\
\hline Cottonseed meal & 0.09 & 0.14 & 0.18 & 0.19 & 0.01 & 0.0035 & 0.2865 & 0.8839 \\
\hline Sunflower meal & 0.07 & 0.09 & 0.11 & 0.17 & 0.01 & 0.0042 & 0.1871 & 0.5873 \\
\hline Jatropha meal & 0.12 & 0.16 & 0.22 & 0.24 & 0.00 & $<0.0001$ & 0.0106 & 0.0013 \\
\hline \multicolumn{9}{|c|}{ Gas production $\mathrm{mg}^{-1}$ of $\mathrm{pFOM}$} \\
\hline Castor meal & 0.04 & 0.05 & 0.07 & 0.08 & 0.00 & $<0.0001$ & 0.1955 & 0.6521 \\
\hline Soybean meal & 0.05 & 0.07 & 0.08 & 0.10 & 0.00 & $<0.0001$ & 0.1245 & 0.8650 \\
\hline Dried corn distillers' grains with solubles & 0.05 & 0.08 & 0.10 & 0.11 & 0.00 & $<0.0001$ & 0.1355 & 0.5688 \\
\hline Dried brewer's yeast & 0.05 & 0.07 & 0.10 & 0.14 & 0.01 & 0.0146 & 0.4928 & 0.9931 \\
\hline Bean residue & 0.07 & 0.10 & 0.12 & 0.15 & 0.00 & $<0.0001$ & 0.2320 & 0.3357 \\
\hline Wet brewer's grain & 0.05 & 0.07 & 0.10 & 0.12 & 0.00 & $<0.0001$ & 0.0555 & 0.5975 \\
\hline Cottonseed meal & 0.04 & 0.06 & 0.08 & 0.09 & 0.00 & 0.0035 & 0.2865 & 0.8839 \\
\hline Sunflower meal & 0.04 & 0.06 & 0.07 & 0.11 & 0.00 & 0.0042 & 0.1871 & 0.5873 \\
\hline Jatropha meal & 0.04 & 0.06 & 0.08 & 0.09 & 0.00 & $<0.0001$ & 0.0106 & 0.0013 \\
\hline
\end{tabular}

'SEM: standard error of the mean; ${ }^{*} P$-value: $P<0.05$. 


\section{Conclusion}

Fermentation parameters of roughage and concentrated foods were influenced as a function of the amount of incubated sample. However, as the total gas production was correlated with potentially fermentable organic matter and the content of potentially digestible carbohydrates, the fermentation pattern was likely not influenced by increasing the amount of incubated sample. Another concern was that the headspace could prevent the storage of gases, affecting the fermentation of food; however, for most foods, gas production by available headspace showed linear increase, and thus was not affected by the amount of incubated sample.

\section{References}

Campos, F. P., Lanna, D. P. D., Bose, M. L. V., \& Boin, C. (2000). Avaliação do Sistema de Monitoramento Computadorizado de Digestão in vitro. 1. Testes Preliminares. Revista Brasileira de Zootecnia, 29(2), 525-530. doi: 10.1590/S1516-35982000000200028

Casali, A. O., Detmann, E., Valadares, S. C., Fo , Pereira, J. C., Henriques, L. T., Freitas, S. G., \& Paulino, M. F. (2008). Influência do tempo de incubação e do tamanho de partículas sobre os teores de compostos indigestíveis em alimentos e fezes bovinas obtidos por procedimento in situ. Revista Brasileira de Zootecnia, 37(2), 335-342. doi: 10.1590/S151635982008000200021

Cone, J. W., \& Van Gelder, A. H. (1996). Influence of rumen fluid and substrate concentration on fermentation kinetics measured with a fully automated time related gas production apparatus. Animal Feed Science and Technology, 61(1-4), 113128. doi: 10.1016/0377-8401(96)00950-9

Detmann, E., Souza, M. A., Valadares, S. C., F' ${ }^{o}$,ueiroz, A. C., Berchielli, T. T., Saliba, E. O. E.,... Azevedo, J. A. G. (2012). Métodos para análise de alimentos. Viçosa, Minas Gerais: Universidade Federal de Viçosa.

Getachew, G., Blummel, M., Makkar, H. P. S., \& Becker, K. (1998). In vitro gas measuring techniques for assessment of nutritional quality of feeds: a review. Animal Feed Science and Technology, 72(3), 261281. doi: 10.1016/S0377-8401(97)00189-2
Getachew, G., Robinson, P. H., DePeters, E. J., \& Taylor, S. J. (2004). Relationships between chemical composition, dry matter degradation and in vitro gas production of several ruminant feeds. Animal Feed Science and Technology, 111(1), 57-71. doi: 10.1016/ S0377-8401(03)00217-7

Goering, H. K., \& Van Soest, P. J. (1970). Forage fiber analysis: Apparatus, reagents, procedures and some applications. Washington: USDA.

Goes, R. H. T. E B., Souza, K. A., Patussi, R. A., Cornelio, T. C., Oliveira, E. R., \& Brabes, K. C. S. (2010). Degradabilidade in situ dos grãos de crambe, girassol e soja, e de seus coprodutos em ovinos. Acta Scientiarum, 32(3), 271-277. doi: 10.4025/ actascianimsci.v32i3.7913

Groot, J. C. J., Cone, J. W., Willians, B. A., Debersaques, F. M. A., \& Lantinga, E. A. (1996). Multiphasic analysis of gas production kinetics for in vitro fermentation of ruminant feeds. Animal Feed Science and Technology, 64(1), 77-89. doi: 10.1016/S03778401(96)01012-7

Menke, K. H., Raab, L., Salewski, A., Steingass, H., Fritz, D., \& Schneider, W. (1979). The estimation of the digestibility and metabolizable energy content of ruminant feeding stuffs from the gas production when they are incubated with rumen liquor in vitro. The Journal of Agricultural Science, 93(1), 217-222. doi: $10.1017 / \mathrm{S} 0021859600086305$

McDougal, E. I. (1949). Studies on ruminal saliva. 1. The composition and output of sheep's saliva. Biochemical Journal, 43(1), 99-109. doi: 10.1042/ bj0430099

Ramin, M., \& Huhtanen, P. (2012). Development of an in vitro method for determination of methane production kinetics using a fully automated in vitro gas system A modelling approach. Animal Feed Science and Technology, 174(4), 190200. doi: 10.1016/j.anifeedsci.2012.03.008

Rymer, C., Huntington, J. A., Williams, B. A., \& Givens, D. I. (2005). In vitro cumulative gas production techniques: History, methodological considerations and challenges. Animal Feed Science and Technology, 123-124, 9-30. doi: 10.1016/j. anifeedsci.2005.04.055

Santo, A. X., Silva, L. D. F., Lançanova, J. A. C., Ribeiro, E. L. A., Mizubuti, I. Y., Fortaleza, A. P. S.,... Massaro, F. L., Jr. (2017). Fracionamento de carboidratos e proteínas, cinética de degradação ruminal in vitro pela técnica de produção de gás, de rações suplementares contendo torta de girassol. 
Arquivo Brasileiro de Medicina Veterinaria e Zootecnia, 69(1), 234-242. doi: 10.1590/1678-41628761

Statistical Analysis System. SAS/STAT Software Version 9.2. Cary: SAS Institute Inc., 2008.

Schofield, P., Pitt, R. E., \& Pell, A. N. (1994). Kinetics of fiber digestion from in-vitro gas-production. Journal of Animal Science, 72(11), 2980-2991. doi: $10.2527 / 1994.72112980 \mathrm{x}$
Sniffen, C. J., O’Connor, D. J., Van Soest, P. J., Fox. D. G., \& Russell, J. B. (1992). A net carbohydrate and protein system for evaluating cattle diets: carbohydrate and protein availability. Journal of Animal Science, 70(11), 3562-3577. doi: $10.2527 / 1992.70113562 \mathrm{x}$

Theodorou, M. K., Williams, B. A., Dhanoa, M. S., McAllan, A. B., \& France, J. (1994). A simple gas production method using a pressure transducer to determine the fermentation kinetics of ruminant feeds. Animal Feed Science and Technology, 48(34), 185-197. doi: 10.1016/0377-8401(94)90171-6 